\title{
FOREIGN STUDENTS SPEECH ADAPTATION TO PROFESSIONAL TRAINING
}

\author{
Natalia Skybun \\ Candidate of Pedagogical Sciences, Senior Lecturer at the Department of Language Training \\ Bogomolets, National Medical University, Ukraine \\ e-mail: skibun_n@i.ua, orcid.org/0000-0003-2962-4725
}

\section{Summary}

The article considers the issue of adaptation of foreign students to the language, sociocultural and everyday environment for further professional training in higher education institutions of other countries. Further integration of national economies into the global world economy creates the preconditions for the emergence of a global labor market, which in turn requires a significant number of professionals who can design and implement ambitious largescale projects. This requires a coordinated work, a high level of communication (especially speaking and communicative) to work in international multi teams. This has created a demand for professionals who have the appropriate training, regardless of the place of education, knowledge, skills and competencies, which require some unification, universalization and standardization at the national level. Further formation of the world global educational space. This requires a high level of communicative, linguistic and speech competences (knowledge of the language at the scientific level) of future students for their professional training outside their country, which needs the appropriate speech adaptation in a foreign language environment. To achieve this goal, it is proposed to carry out adaptation with the help of online (virtual) preparatory faculties (hereinafter - OVPF), which takes on all issues related to the adaptation of future foreign students in the new linguistic, scientific, sociocultural, everyday dimensions, as well as in further educational spheres (medical, humanitarian, physical-mathematical, linguistic, etc.). The introduction of the online (virtual) preparatory faculties makes it possible to adapt future foreign entrants / students at their homes. An important element of the preparatory faculties are local lore studies. At the same time, OVPF is proposed as a separate universal global educational product that can be placed on world educational platforms, portals and websites.

Keywords: Ukrainian language as a foreign language, language environment, sociocultural and everyday environment, competencies, basic level of competencies and knowledge, adaptation of foreign students, speech adaptation, preparatory faculty, local lore studies.

\section{DOI: https://doi.org/10.23856/4910}

\section{Introduction}

Modern digital and mobile technologies are creating a new global (worldwide) information and transport infrastructure, which increasingly include/integrate the national elements of the information and transport infrastructure of many countries. In addition, a significant number of projects are being implemented, which are initially global in nature. Such transformational and integration processes form the global economic space and the global labor market in the conditions of multinationalism, multiculturalism, multireligiousness (hereinafter - multisms), freedom (personal and social), human dignity and tolerance. Further growth of open borders creates the emergence of an open mobile society, when tourism (educational, labor, medical, 
cultural) opens national borders, culture, traditions, customs and world of life. In addition, the global labor market creates a demand for a similar global market for educational services, when the acquisition of vocational education, skills, knowledge and competencies loses national borders, and education in higher education institutions (hereinafter - HEI) of any member country meets the standards and requirements established. Nowadays Ukraine has been and remains attractive to foreign applicants for a number of reasons: «geographical location as a potential provider of educational services to East and Asia is favorable, the cost of education and accommodation is relatively low, there are powerful research and educational centers are (Kiev, Lviv, Odessa, Kharkiv, Dnipropetrovsk, Donetsk, Vinnytsia, Ivano-Frankivsk), higher education institutions are capable to provide quality education» (Pidhotovka fakhivtsiv, 2010). Thus, in Ukraine «medical and pharmaceutical specialties are the most popular among foreign citizens», and therefore «16 higher medical educational institutions of Ukraine train foreign specialists» (Kalashnik, 2016: 60) in these specialties. According to the Ukrainian State Center for International Education, «the vast majority of foreign students are from Asia (Iraq, India, Syria, Turkey), Africa (Morocco, Nigeria, Cameroon), CIS countries (Azerbaijan, Turkmenistan)»(Hantimurova, 2019: 6). Considering the above, the main tasks facing the domestic HEIs and the country's authorities are to preserve and increase the capacity to provide educational services to foreign students according to the world standards. On the one hand, domestic HEIs and national infrastructure can earn a decent amount of money, and on the other hand, the entry of domestic educational space into the global world educational space will only improve the quality of education. This can be achieved only by constantly improving the educational processes, curricula and methods of teaching, first of all, Ukrainian as a foreign language, because education in our country is carried out only in the state language (Ukrainian). Thus, M. Tsurkan «notes that the formation of the professional competence, which includes various competencies (language, speech, communication, socio-cultural and others), in the process of becoming a future doctor requires interdisciplinary justification of the integrated model, improving the content, forms and methods of teaching, creating favorable psychological and pedagogical conditions for practical learning activities» (Tsurkan, 2019: 51). The domestic HEIs can be an example as they closely cooperate with the leading HEIs of other countries, first of all the EU countries. This became possible because of the borders opening and an increasing in the level of autonomy and freedom of both the HEIs themselves and the teaching staff and students. Thus, the speaking adaptation of foreign students to professional training is the key to the formation of professional competence, skills and gaining competitive professional knowledge and skills in the global labor market.

The analysis of recent research and publications has shown that the question of the foreign students studying adaptation has been studied by many modern researchers and scholars.

The analysis of recent research and publications has shown that the issues of adaptation of foreign students have been studied by such researchers as: I. Alekseenko, A. Hadomska, N. Hantimurova, I. Horishniy, P. Hoshchinsky, L. Dzyubenko, L. Kaidalova, N. Kalashnik, T. Kononova, I. Krytsky, T. Krytsky, G. Krytska, T. Kudina, M. Kushnirov, V. Lyubarets, O. Matviychuk, O. Mochulska, N. Nikolaeva, Y. Rudyak, V. Serhienko S. Sysoeva, N. Fedchyshyn, I. Fomin, J. Cherkashina, N. Chernenko, M. Tsurkan, etc.

Despite the wide range of research on the adaptation of foreign students to studying in domestic higher education institutions, the problem of foreign students' speech adaptation to training is a part of the general problem to which this article is devoted. The aim of the article is to study the impact of speech adaptation of foreign students to professional training (acquisition of professional knowledge, competencies and skills). The research methods used in the process 
of writing the article involve the use of general scientific and empirical techniques based on a systematic approach. In addition, general research methods such as generalization and comparison were used in the process. As a result of the analysis, the main range of issues that arise in the study of the impact of speech adaptation of foreign students to training (acquisition of professional knowledge, competencies and skills) is identified.

\section{Speech and professional competence of foreign students}

The current stage of the society civilizational development is characterized by such features as: education, knowledge, competence. This is due to the rapid development of science and technology, as well as the widespread introduction of the results into industrial use. That is why today a high-class professional who can work in an international team at any corner of the globe is in demand. Recently, more and more large-scale infrastructure, environmental, scientific, medical, socio-cultural and socio-domestic projects are being designed and built, which require a large number of highly qualified specialists and scientists. As for Ukraine, today Ukrainian specialists participate in the international projects outside the country, as well as work in international groups while designing and constructing various projects. As for educational services for foreign students, Ukraine has quite a lot of experience and potential in terms of teaching foreign students, because even in Soviet times, students from many countries and the republics of the USSR studied in the UkrSSR. However, the educational process has been carried out mainly in Russian, and therefore it requires a restructuring of teaching in Ukrainian.

Some difficulties in the process of adaptation and transition to Ukrainian-language education of foreign students is that the Ukrainian language is not included into the list of languages of intercultural communication, and the geography of its study is quite fragmentary and uncommon, so we have a small percentage of future entrants seeking education, who speak Ukrainian at least at the household level. That is why the speech adaptation of foreign students to professional training is extremely important and necessary, as the acquisition of professional knowledge, competencies, skills and abilities requires a sufficiently high level of language and speech competencies. Thus, T. Kononova is convinced that «in order for a foreign student to become a full-fledged specialist during the years of study in the HEI, it is necessary to conduct a comprehensive analysis of foreign students' education in different countries over the past decade, the development of conceptual bases for reforming the system of foreign specialists training in Ukraine for foreign countries under the new political, economic and social conditions, taking into account that the training of future professionals today must be based on a symbiosis of educational and professional activities, a combination of general education and training, the use of modern information technology» (Kononova, 2013: 252). As it is stated in the Unified standard curriculum in the Ukrainian language for foreign students of the main faculties of non-philological profile of higher educational institutions of Ukraine III-IV levels of accreditation, «the communicative purpose of education is the main, as both the educational and upbringing goals are realized under the condition that students achieve a certain level of language proficiency. It is achieved by forming students' necessary language and speech skills in all types of speech activities (reading, listening, speaking, writing), providing them with the opportunity to communicate in the Ukrainian language environment (learning, life, culture) and obtaining a specialty» (Kaidalova, 2011). It should be taken into account that «the ultimate goals of training foreigners are partially or fully realized under the condition of organizing a clear phased implementation of a specific system of tasks» (Kalashnik, 2016: 60-61). Thus, a number of researchers under the «professional competence of the future doctor» suggest to understand as «theoretical and practical training of 
the student on the basis of personal and professionally important qualities; the state of formation of professional knowledge, skills, values, speech culture, communication style, analytical, prognostic, design skills necessary to perform the activities of a doctor», and the process of forming this competence in higher medical education should be considered as a «process of mastering sustainable, integrated, systematic knowledge of natural sciences, humanities, fundamental and clinical disciplines; ability to apply them in new, non-standard situations; development of personally important qualities and professionally important qualities that will ensure the personal development of the future doctor» (Krytskyi, 2018: 46). S. Sysoyeva, in turn, notes that «competence» is «an integrated personal quality of a person (his capital), which is formed at the stage of training, finally formed and developed in the process of practical activities and provides a competent approach to solving professional problems» (Sysoieva, 2015: 8), and therefore the level of knowledge of the language depends not only on its competence, but also competency, which acts as a «dynamic combination of knowledge, skills and practical skills, ways of thinking, professional, ideological and civil qualities, moral and ethical values, which determines a person's ability to successfully carry out professional and further educational activities and is the result of education at a certain level of higher education» (Pro vyshchu osvitu, 2014). It is common now to receive and continue education (continuing education) in different free educational institutions in different countries, when a foreign student not only receives his first education, but also continues his studies in Ukraine, having a certain level of competence and a wide range of modern competencies. HEIs offer only high-quality and competitive educational product that is unified, standardized with the world product. In addition, it is necessary to take into account that in the current conditions of globalization there is a spreading of relevant languages, which are the basis for communication at the world global and regional global levels. In this regard, as it is noted by M. Tsurkan, «the process of studying in Ukrainian institutions of higher medical education is inherently bilingual», because «most English-speaking foreign students master the profession in English, but «living» in the Ukrainian socio-cultural environment, the study of clinical disciplines on the basis of medical institutions is by learning the Ukrainian language as a foreign language» (Tsurkan, 2019: 51). Despite this, the practical studying is carried out in Ukrainian medical institutions, where communication at the levels doctor-patient, doctor-patientdoctor, doctor-doctor is mostly carried out in Ukrainian, and therefore the level of knowledge of Ukrainian provides the professional activity and determines the competence of a foreign doctor. Therefore, the purpose of foreign students teaching of the Ukrainian language is "students' skills and abilities of speaking activity, which is achieved through a comprehensive approach to training for foreign countries, which combines the interaction of communicative, educational and pedagogical goals» (Iedyna typova prohrama, 2008: 4). That is why «a foreign language in the process of such learning is not only a means of communication, but also a tool for learning about the world, acquiring professional knowledge and skills, achieving a high level of language and speech competence» (Kushnirov, 2014: 252). In our opinion, such «bilingualism» of foreign students is very useful when studying in domestic HEIs, because it provides a similar «bilingualism» among teachers and methodologists and provided skillful use/combination during educational processes will only enhance communication, language and speaking competencies both among foreign students and among the teaching and methodological staff of the domestic HEIs.

\section{Adaptation of foreign students to professional training}

It should be taken into account that «special topicality in the training of foreign students future doctors, who stay in the new social conditions of another country for 6-7 years, acquires 
the formation of their readiness to communicate in Ukrainian during their studying and medical practice, which requires the improvement of educational process in HEIs through the use of pedagogical innovations» (Hantimurova, 2019: 6). Thus, L. Kaidalova and J. Cherkashin, considering «the peculiarities of foreign citizens training in preparatory faculties in higher education institutions», note the following: «training of foreign students at the preparatory faculty at the National University of Pharmacy is a special initial stage of study» for «a short time (8-10 months) students must not only acquire a sufficient amount of theoretical knowledge... of the literary language, but also create their own lexical base, form language, communication skills and abilities that will be necessary for them to participate fully in the life of the university. First of all, it should contribute to "creating all the necessary conditions for the rapid adaptation of foreigners in the new socio-cultural environment» (Kaidalova, 2011), which is quite positive for adaptation. According to V. Lyubarets, «socio-cultural environment as a system covers various types of cultural activities that are formed in society and become the object of study and the subject of study of various industries», as well as «socio-cultural environment is manifested in personal growth (self-determination, self-development, self-realization) through the interaction of structures of socio-cultural activities (personal development, cultural, creative and professional experience)» (Liubarets, 2019: 55). O. Matviychuk notes that «the preparatory department for foreign citizens is the first step in mastering the base of knowledge, skills and abilities in the field of future profession», as «teaching studying physics by foreign citizens in the preparatory department is a complex, branched, creative process, depending on many factors: the initial level of training, the mental state of students in the period of adaptation, the ability to learn information in a foreign language and many others», and therefore «students of the preparatory department during training must acquire a basic set of knowledge, skills and abilities in physics» (Matviichuk, 2006: 196). That is why the problems of adaptation are always relevant for both future foreign entrants and freelancers, because «a foreign medical student has to solve various problems that require the formation of skills and knowledge in such subfields of educational and professional activities as: listening to lectures; preparation for practical classes; work in the laboratory; consultations; assembly of modular controls; registration of laboratory, scientific works or abstracts; preparation of reports and messages and presentations; participation in clinical and pharmaceutical practice, etc.» (Kalashnik, 2016: 60-61). At the same time, it is also necessary to provide a comprehensive approach to the adaptation of foreign students both before the start of studies (preparatory faculty) and during the study, especially during the first years (the first and the second year). The peculiarity and complexity of free economic education, teaching and methodology staff is the formation of intercultural communicative competence of future foreign doctors in a multidisciplinary environment, which is a modern domestic educational space, where foreign students from different countries of near and far abroad receive the professional education. However, it should be taken into account that despite the «multism», the best results are achieved in multicultural and multilingual groups during the adaptation/training of future students in preparatory faculties, consisting of people from one region and/or country, or when studying directly in educational groups. Today, thanks to digitalization, computerization and the widespread introduction of information and communication technologies, informatization of the educational processes, the problem of foreign students' adaptation to the language, socio-cultural, everyday environment is reaching a new modern level. The main feature of modern digital society is the virtualization of the educational process (adaptation process), which «eliminates» many problems arising during similar activities in the physical space. First of all, it is necessary to note the possibilities of distance learning or so-called online learning, when applicants and/or students communicate, 
adapt, learn virtually, even without leaving their homes. It is also necessary to pay attention to the author's video lessons, online lessons, etc. developed and implemented in wide (open) access. Thus, modern digital, technical, technological and infrastructural capabilities make it possible to open online (virtual) preparatory faculties (hereinafter - OVPF), where the foreign entrants are adapting in the virtual space and are preparing («leveling» of knowledge) for the direct learning (obtaining vocational education). This opens new opportunities both for the processes of adaptation and for the educational processes not only of the domestic HEIs, but practically of all the HEIs that carry out and/or wish to train specialists using the Ukrainian language. According to V. Serhienko, in the framework of training (adaptation) of foreign students at preparatory faculties and/or departments, the following results can be achieved, namely: «acceleration of adaptation to the educational process in new conditions; developing the ability to perceive the scientific style of language and understanding the text of teaching materials in physics in the language of instruction; systematization and adjustment of knowledge; developing the ability to transform this knowledge to acquire a highly professional new level that will allow you to become competent in your field; development of the ability to acquire skills for independent performance of educational tasks; development of the ability to think logically; education of sustainable interest and the need for continuous acquisition of knowledge, professional self-improvement» (Matviichuk, 2006: 196).

\section{The use of local lore studies within the preparatory faculties}

Virtual local lore studies (hereinafter - VLLS) can be considered as one of the important elements of the online (virtual) preparatory faculties. In our opinion, it would be appropriate to use the opportunities of local history studies to study the Ukrainian language, socio-cultural and everyday adaptation of future entrants in the framework of the preparatory faculties at both physical (traditional) and virtual levels. As I. Alekseenko emphasizes, «customs, traditions, culture, environment, nature, historical monuments, prominent people - this is the range of interests that covers local lore and which is often the subject of communication with representatives of other cultures», because «under the influence of a number of factors, both linguistic and sociocultural, the concept of the «language learning» is gradually being replaced by the new one - the «language and culture learning», in particular the culture of interpersonal communication of subjects belonging to different societies», and «therefore the use of the local history material coincides with the cultural approach in foreign languages teaching», when the concept of «culture» is invested in a set of many factors (material and spiritual content) that surround the person and contribute to his socialization in the society» (Alieksieienko, 2014: 12-13). Today, the list of virtual museums, exhibitions, historical reconstructions where you can get acquainted with the cultural heritage of Ukraine is being formed and constantly expanding, as well as the library of audio and video materials about culture is increasing. And this makes it possible to combine local history studies at the physical and virtual levels. Therefore, in the framework of the OVPF creation it is appropriate to include the work of VLLS into their training programs. After all, according to I. Alieksieienko, «working on local lore research is a holistic and consistent system, which is implemented in stages: presentation of the problem; determination of the main directions of research of this problem, the purposes, tasks, ways of its decision, preliminary planning of work; creation of creative groups; organization of search and research activities to solve problems; systematization and registration of the results of local lore research activities; presentation of the final results of the study; conclusions, discussion of the results of the work» (Alieksieienko, 2014: 13). 
In addition, training within the OVPF should be almost identical to the one taking place in the HEI, namely: grouping, appointment of the head, appointment of the curator-teacher, control and monitoring of the educational process, checking the knowledge, deductions, constant communication at the level teacher-student, teacher-students, student-student, etc. That is, in fact, we are talking about the «light version of the 1st year of studying». And most importantly, all this can be done online, and therefore, in case of problems with adaptation, the future foreign entrant or foreign student can decide on further study in the HEI of Ukraine with less losses (moral, image and financial). Thus, the creation and implementation of such online (virtual) preparatory faculties will increase the efficiency of adaptation of foreign students for further study in HEIs of Ukraine. At the same time, the State Standard on Ukrainian as a Foreign Language stipulates that at the initial level of language proficiency, a foreign communicator must be guided in the texts of domestic, socio-cultural, educational (training) and regional studies topics. Texts on this topic are processed during the implementation of all types of speech activity of a foreign communicator (Derzhavnyi standart z ukrainskoi movy, 2012). Continuing the idea of creating, scientific and methodological content and use in OVPF educational processes in relevant professional areas (e.g., medical, physical and mathematical, engineering, linguistic) can be offered as a holistic separate educational product.

Also, the basis for «the choice of forms and methods of teaching foreign citizens» should be «the formation of knowledge, skills and abilities carried out in the process of studying and learning activities of the person», as well as «the management of the cognitive activity» as: «the reliance on mental and regional characteristics of foreign students (taking into account their adaptation); subject orientation and subject relations between the teacher and the foreign student; unity of goals and motivation of study in the native country and in the preparatory department; priority of feedback results for adjustment of the educational process» (Matviichuk, 2006: 196). Thus, after graduating from the OVPF it is possible to provide for the issuance of a certificate (based on test results), with which the future foreign student can be enrolled to any HEI of the relevant profile. It should be taken into account that future foreign entrants who will undergo speech, professional, socio-cultural, household adaptation at the preparatory faculties or OVPF must be clearly aware that they actually pay money not for the certificate of completion of the preparatory department, but for the preparation to successful studying in the higher education institution of Ukraine. In this regard, there should be strict control over the provision of educational services within the certified OVPF. You can also consider the feasibility of forming study groups by testing, as well as the adjusting the curriculum for these study groups. For example, if the future student already speaks Ukrainian at the level of A1 and A2, then he can continue studying the Ukrainian language in this group from the level of A2 to the level of B1 and B2. Similarly, it is possible to form groups and educational processes for foreign students who have an intermediate level of basic knowledge in the subjects included into vocational training. These OVPF should be placed on the platforms of the HEIs. In addition, the possibility of placing such OVPFs on global world educational platforms can be considered. In our opinion, the introduction of OVPF instead of traditional preparatory faculties will increase the number of foreign students in the domestic HEIs, as the speaking adaptation together with the professional, sociocultural and household ones can be purchased online at lower price and cost for foreign students during their stay in the country, and that will be appreciated by students from poor countries. Thus, T. Kudina proposes to carry out «the formation of the foreign students' Ukrainian language lexical competence at the preparatory departments» through the introduction of the use of network multimedia educational and methodological complex «Ukrainian language for foreigners» (Kudina, 2013), which to some extent can be used to 
create OVPF and VLLS. For their part, the developers of the «Program for the Ukrainian language as a foreign language» A. Berezovenko, L. Dzyubenko, T. Shevchuk «focus on the use of modern information technology (e.g., the use of elements of cyber communication, Skype and video conferencing)» (Hadomska, 2017: 61- 62). Quite creatively and logically, the online format of adaptation can include the creolized texts of Ukrainian-language advertising, which are often distributed through the mass media. Thus, according to A. Hadomska, «the creolized texts of Ukrainian-language advertising are convenient, capacious and perspective material for the constant replenishment of their active and passive vocabulary with vocabulary from almost all spheres of public life; ... Creating situations of real communication where they have the opportunity to realize their cultural knowledge background, practically apply the grammar of the Ukrainian language» (Hadomska, 2017: 52). The above allows us to say that working on the latest teaching methods is quite active, including domestic teachers, scientists and methodologists, and this creates the conditions for the emergence of a domestic competitive educational product that can be posted on the world educational resources, sites and platforms.

\section{Conclusions}

Summarizing the study of the role of the speaking adaptation of foreign students to vocational training while studying in the domestic HEIs, it should be noted the following. Due to the further integration of national economies into the global world economy, a global labor market is emerging, that requires a significant number of professionals who design and implement various projects within international teams. All this requires serious training, which must take place on a unified, universal and standardized educational global world platform. Therefore, there is a need for speaking adaptation in a foreign language environment. We have proposed the adaptation through online (virtual) preparatory faculties, which should take on all issues related to the adaptation of the future foreign student in the new language, scientific, socio-cultural, domestic and professional dimensions («light version of the 1st year»). We also note that these OVPF must have modern programs and teaching methods (created in accordance with international standards), on the basis of which the future foreign students will be able to continue their studies not only in the HEI where he was adapted, but also in any other HEI. As one of the important elements of the preparatory faculties, we recommend to include local history studies and online (virtual) local history studios. The virtualization of the educational processes for the adaptation of future entrants will contribute to: saving money on education, the spread of those wishing to receive education in the Ukrainian HEIs. As a result, OVPF can act as a separate universal global educational product and be hosted on leading educational platforms, portals and websites.

\section{References}

1. Alieksieienko I. V. (2014) Realizatsiia kraieznavchoho komponentu zmistu navchannia inozemnoi movy u starshii shkoli (na materiali elektyvnoho kursu z anhliiskoi movy) [Implementation of the local history component of the content of foreign language teaching in high school (on the material of an elective course in English)]. Naukovyi visnyk Uzhhorodskoho natsionalnoho universytetu. Seriia «Pedahohika, sotsialna robota». Uzhhorod. Vypusk 32. [in Ukrainian]. 2. Hadomska A. A. (2017) Metodyka movlennievo-kulturnoi adaptatsii inozemnykh studentiv zasobamy kreolizovanykh reklamnykh tekstiv. [Methods of speech and cultural adaptation of foreign students by means of creolized advertising texts]: 13.00.02. dyser. na zdob. nauk. stup. kand. ped. nauk. Odesa. [in Ukrainian]. 
3. Hantimurova N. I., Fedchyshyn N. O., Rudiak Yu. A. (2019) Profesiina pidhotovka studentiv-inozemtsiv u medychnykh universytetakh Ukrainy. [Professional training of foreign students in medical universities of Ukraine]. Pidvyshchennia yakosti vyshchoi medychnoi osvity. Medychna osvita. № 4. [in Ukrainian].

4. Derzhavnyi standart z ukrainskoi movy yak inozemnoi. I serednii riven (V1). (2012) [State standard for Ukrainian as a foreign language. And the average level (B1)]. Kyiv: [KNU imeni K. D. Shevchenka]. [in Ukrainian].

5. Iedyna typova navchalna prohrama z ukrainskoi movy dlia studentiv-inozemtsiv osnovnykh fakultetiv nefilolohichnoho profiliu vyshchykh navchalnykh zakladiv Ukrainy III-IV rivniv akredytatsi. (2008) [The only typical curriculum in the Ukrainian language for foreign students of the main faculties of non-philological profile of higher educational institutions of Ukraine III-IV levels of accreditation]. Nauk.-metod. komisiia z pidhot. inoz. hromadian, uklad. Kyiv. [in Ukrainian].

6. Kaidalova L. H. Cherkashyna Zh. V. (2011) Osoblyvosti pidhotovky inozemnykh hromadian na pidhotovchykh fakultetakh $u$ vyshchykh navchalnykh zakladakh. [Features of training of foreign citizens at preparatory faculties in higher educational institutions]. Problemy trudovoi ta profesiinoi pidhotovky. Ser. Problemy onovlennia zmistu pedahohichnoiosvity v umovakh yevrointehratsii. Vypusk. 19. [in Ukrainian].

7. Kalashnik N. V. (2016) Osoblyvosti osvitno-vykhovnoi roboty z inozemnymy studentamy $u$ vyshchykh medychnykh navchalnykh zakladakh Ukrainy. [Features of educational work with foreign students in higher medical educational institutions of Ukraine]. Pedahohichni nauky. Vypusk 1(83). [in Ukrainian].

8. Kononova T. O. (2013) Analiz problemy profesiinoi pidhotovky inozemnykh studentiv u VNZ Ukrainy. [Analysis of the problem of professional training of foreign students in Ukrainian universities]. Problemy inzh.-ped. osvity : zb. nauk. pr. / Ukr. inzh.-ped. akad. Kharkiv: UIPA, № 38/39. [in Ukrainian].

9. Krytskyi I. O., Hoshchynskyi P. V., Krytskyi T. I., Horishnii I. M., Mochulska O. M., Krytska H. A. (2018) Formuvannia profesiinoi kompetentnosti maibutnoho likaria na prykladi studentiv medychnoho fakultetu TDMU. [Formation of professional competence of the future doctor on the example of students of the medical faculty of TSMU]. Medychna osvita. № 3. [in Ukrainian].

10. Kudina T. M. (2013) Formuvannia leksychnoi kompetentnosti ukrainskoi movy v inozemnykh slukhachiv pidhotovchykh viddilen [Formation of lexical competence of the Ukrainian language in foreign students of preparatory departments]. avtoref. dys. ... kand. ped. nauk: 13.00.02. Kyiv. [in Ukrainian].

11. Kushnirov M. O. (2014) Suchasni pidkhody do navchannia inozemnoi movy: oriientatsiia na tsinnosti osobystisnoho rozvytku y humanizmu. [Modern approaches to foreign language teaching: focus on the values of personal development and humanism]. Pedahohichni nauky: teoriia, istoriia, innovatsiini tekhnolohii. № 8 (42). [in Ukrainian].

12. Liubarets V. V. (2019) Teoriia i praktyka profesiinoi pidhotovky maibutnikh menedzheriv sotsiokulturnoi diialnosti $v$ umovakh informatsiino-osvitnoho seredovyshcha. [Theory and practice of professional training for social and cultural managers in the minds of the information and educational center] : avtoref. dys. ... d-ra ped. nauk : 13.00 .04 / V. V. Liubarets. Kyiv. [in Ukrainian].

13. Matviichuk O. V. (2006) Osoblyvosti navchannia fizyky inozemnykh studentiv na pidhotovchomu viddilenni tekhnichnoho universytetu. [Features of teaching physics to foreign students at the preparatory department of the Technical University]. Zbirnyk naukovykh prats. 
Pedahohichni nauky / Khersonskyi derzhavnyi universytet. Kherson: Vyd-vo KhDU, Vyp. 43. [in Ukrainian].

14. Pidhotovka fakhivtsiv dlia inozemnykh krain u vyshchykh navchalnykh zakladakh Ukrainy [Training of specialists for foreign countries in higher educational institutions of Ukraine]: problemy ta perspektyvy rozvytku. (2010) zb. materialiv mizhnar. nauk.-prakt. konf. 24-25 cherv. 2010 r. / red. kol.: N. M. Chernenko, I. L. Fomina. Odesa: PNPU imeni T. G. Ushynskoho. [in Ukrainian].

15. Pro vyshchu osvitu. [About higher education]. (2014) zakon Ukrainy. Vidomosti Verkhovnoi Rady Ukrainy vid 19.09.2014 / № 37-38 /, stor. 2716, stattia 2004. [in Ukrainian].

16. Sysoieva S. O. (2015) Kompetentnisno zoriientovana vyshcha osvita: formuvannia naukovoho tezaurusu. [Competence-oriented higher education: the formation of a scientific thesaurus]. URL : https://elibrary.kubg.edu.ua/id/eprint/11033/1/Sysoeva\%20S.A.\%202015.pdf. [in Ukrainian].

17. Tsurkan M. (2019) Formuvannia profesiinoi movlennievoi kompetentnosti inozemnykh studentiv-medykiv na zaniattiakh z ukrainskoi movy. [Formation of professional speech competence of foreign medical students in Ukrainian language classes]. Neperervna profesiina osvita: Teoriia i praktyka (Seriia: Pedahohichni nauky) Vypusk № 3(60). [in Ukrainian]. 